\title{
RESEARCH FINDINGS ON THE EVOLUTION OF PEACEKEEPING
}

Theodora-Ismene Gizelis (University of Essex), Han Dorussen (University of Essex) and Marina Petrova (University of Essex)

\section{Article Summary:}

Peacekeeping has evolved both in its focus and in setting increasingly ambitious goals. In effect, the referent object of peacekeeping-what and whose peace is to be kept- has changed. The peace that is to be kept has evolved from a negative conception of peace to encompassing an increasingly positive understanding of peace. Similarly, the object of the peace has shifted from the global to the national and ultimately the local. In effect, this has raised the bar for peacekeeping.

Peacekeeping research has mirrored these changes in the expectations and practice of peacekeeping where the (in)effectiveness of peacekeeping has remained a constant concern. The evaluation has shifted from the authorization and organization of peacekeeping missions to the impact of peacekeepers to avoid the recurrence of conflict, to ultimately the ability of peacekeepers to change the situation on the ground and the interaction between peacekeepers and the local population.

Research on peacekeeping has become increasingly methodologically sophisticated. Originally, qualitative cases studies provided a largely critical evaluation of the effect of peacekeeping. Large-n quantitative studies have reassessed where peacekeepers are deployed and who provides peacekeepers. Controlling for selection bias and possible endogeneity, quantitative research finds peacekeeping makes the recurrence of conflict less likely. Disaggregate data on peacekeeping confirm that peacekeeping contains local conflict and protect local civilian population. At the same time, peacekeepers have only had limited success in positively affecting conflict societies by means of security sector reform and building state capacity. There is little evidence that peacekeeping is able to support democratization and economic development. 


\section{Keywords: Peacekeeping, United Nations, Civil Wars, Mandates, Quantitative Research, Case Studies, Supply of Peacekeepers, 'Peacekept', Positive Peace, Peacebuilding.}

\section{Introduction}

Peacekeeping inevitably has to grapple with what peace and whose peace is to be kept. This would seem obvious for peacekeeping research as well, but over the last sixty years scholars have been mainly concerned with whether peacekeeping ever works. For a long time, research produced a long list of prime suspects for the failures of peacekeeping: the politics behind the authorization of peacekeeping missions, limited or inappropriate mandates, insufficient resources (financially and in troop numbers), etc. There may even have been some 'lessons learned': since the end of the Cold War, the UN has authorized more missions deploying an unprecedented number of peacekeepers. So-called integrated (or complex) missions have been given broader mandates encompassing peacebuilding and even, if deemed necessary, robust peacemaking. An increasing number of countries now contribute peacekeepers both via the United Nations (UN) as well as regional security organizations, most prominently the African Union (AU), European Union (EU) and the Organization of American States (OAS). At the same time, controversies surrounding peacekeeping have hardly diminished, arguably because the ultimate objectives of peacekeeping remain elusive.

Peacekeeping has evolved both in its focus and in setting increasingly ambitious goals. In effect, the referent object of peacekeeping - what and whose peace is to be kept-has changed. The peace that is to be kept has evolved from a negative conception of peace to encompassing an increasingly positive understanding of peace (Galtung 1964). Similarly, the object of the peace has shifted from the global to the national and ultimately the local. Somewhat counter intuitively, this has made the population of the 'peacekept' more inclusive. Whereas originally peacekeeping aimed to secure the objectives of the major powers (that is, the Permanent Five of the UN Security Council) and national elites, its main focus now firmly includes civilians caught up in the fighting and suffering the consequences of poorly governed or failed states. In effect, this has raised the bar for peacekeeping. The expectations of peacekeepers have been heightened both in response to success- 'if peacekeeping 
works in Namibia, it should also work in Cambodia' — as well as failure_- 'if peacekeeping failed in the DRC because of limited resources (restrictive mandate, etc.), it should succeed if the peacekeepers are given more resources (broader mandate, etc.)'.

The agenda of peacekeeping research has to some extent followed these developments. The focus of the study of UN peacekeeping has shifted from the $U N$ to peacekeeping. Originally, (comparative) case studies (Diehl, Reifschneider, and Hensel 1996; Durch et al. 2003; Paris 1997, 2004) examined the legal framework of peacekeeping and the management of peacekeeping operations. The international (UN) level provided the core criteria for success: were missions mandated and deployed in time? Was there sufficient financial and troop support? Initial systemic quantitative studies (Doyle and Sambanis 2000, 2006; Fortna 2003, 2004, 2008a, 2008b) compared peacekeeping missions to evaluate their relative success or failure, where success is defined at the theatre of operations: do peacekeeping operations make it less likely that former combatants return to fighting? They defined durable peace as the absence of armed conflict. In effect, peacekeeping 'works' if it contributes to a negative peace, where peace does not have a specific content, but signifies a situation without battle related deaths.

Recently, research on peacekeeping has definitely gone 'micro'. The experiences of the local population and the (in)ability of peacekeepers to address their urgent concerns have become main topics for research. Accordingly, the core research question no longer focuses on the absence of conflict, but on the impact of peacekeeping on the content and quality of peace, the so-called positive peace. Hultman, Kathman, and Shannon $(2013,2014)$ show that peacekeepers protect civilians against one-side violence highlighting the increasingly humanitarian role of peacekeepers. Increasing availability of data with detailed information on deployment and activities of peacekeepers has encouraged researchers to examine their impact sub-nationally. Ruggeri, Dorussen, and Gizelis (2016a, 2016b) show that robust peacekeeping limits the conflict episodes in specific localities, while Gleditsch and Beardsley (2015) demonstrate how peacekeeping avoids conflict from engulfing countries. Fieldwork and field experiments use increasingly sophisticated research designs to address concerns of peacekeeping and the 'peacekept' directly (Fortna 
2008b; Gilligan, Pasquale, and Samii 2014, Gilligan et al. 2012; Mvukiyehe and Samii 2012). Ethnographic research (Autesserre 2010, 2014) details peacekeeping practices and their failure to secure peace from the bottom-up. In this way research has not only clearly expanded the population of 'peacekept', but also use a positive peacethe improvement of human, political and economic rights—as the yardstick for peacekeeping success.

The remainder of the chapter explores four main themes. The next section considers in greater detail how the evolution of peacekeeping and increasing expectations for the UN to produce both negative and positive peace have shaped the research agenda. Section three reviews the selection of peacekeeping missions and the supply of peacekeepers, while section four considers the findings of quantitative comparative research on the effectiveness of peacekeeping; in other words, the quality of the peace that is kept. In section five, we provide an overview of the recent literature on the local experiences of the 'peacekept'. The conclusions revisit the main theme, namely that research on peacekeeping has steadily increased the standard and expectations for defining successful peacekeeping.

\section{Evolution of Peacekeeping from Negative to Positive Peace}

Originally peacekeeping described observer missions mandated to maintain a truce or cease-fire agreement by keeping the belligerents (usually states) apart. UN peacekeeping built upon the experiences of the League of Nations. Reflecting the post-World War II world, it was not intended as a substitute for sovereignty and limited to address shared concerns of the main global powers; hence the decisive role of the P-5 in mandating peacekeeping missions (Barash and Webel 2002: 351). During the Cold War the UN deployed only a small number of UN peacekeeping missions, commonly described as 'first generation' or 'traditional' peacekeeping missions with an emphasis on impartiality, light armament and peacekeeping by consent (Goulding 1993). The scope of the UN missions was narrow with a focus on monitoring the terms of peace agreements between sovereign states (for example Israel-Syria in the Golan Heights; India-Pakistan in Kashmir). Yet several of these missions have proved to be remarkably long-lived; for example, United Nations Military Observer Group in India and Pakistan (UNMOGIP) in Kashmir has been deployed since 1949. The UN operation in Congo (ONUC) in 1960 was the first time 
the UN attempted at peacekeeping in an intrastate conflict. It was generally considered as a failure, which further restricted the willingness of the UN to engage in peacekeeping. For the next thirty years, the UN mandated only a few small missions for a short period, such as the Mission of the Representative of the Secretary-General in the Dominican Republic (DOMREP), and the longer but very small deployment to Cyprus (UN Peacekeeping Force in Cyprus-UNFICYP). Generally a few small and neutral countries such as Sweden and the Fiji Islands provided the majority of peacekeepers.

The end of the Cold War not only changed the nature of international conflict and threats to international security, but also increased the space for cooperation among the permanent members of the Security Council (P-5). New security threats affected the nature of peacekeeping missions (Chesterman 2005; Diehl and Balas 2014; Doyle and Sambanis 2006). In the 1990s the erosion of state legitimacy emerged as a primary threat to state, regional and even global security. In the aftermath of conflict, the absence of central and competent state authority not only undermines the prospects for peace. It also destabilizes the political situation in the region (Duffield 2014; Migdal 1998; Nixon 2006; Rotberg 2002). In response, UN missions slowly transformed in order to substitute for the lack of state capacity and to improve governance (Doyle and Sambanis 2000). There was a dramatic surge in both number of missions but also size of missions in terms of personnel. In a very short period from 1989 to 1994, the UN Security Council authorized 20 new missions increasing the number of peacekeepers from 11000 to 75000 . So-called 'second' and 'third'generation peacekeeping missions replaced the 'traditional' model of peacekeeping (Goulding 1993). Third-generation missions moved beyond observational tasks to complex 'multidimensional and integrative missions' with more ambitious goals to promote complex peace agreements and to sustain peace in the post-conflict period (Tiernay 2015).

After the Brahimi report (2000), peacebuilding became a primary focus of UN peacekeeping. The more comprehensive agenda of peacekeeping includes humanitarian assistance, disarmament and re-integration of combatants (DDR), security sector reform (SSR), promoting human rights and reestablishment of rule-oflaw, organizing democratic elections and supporting economic development and 
social justice (Boutros-Ghali 1992; UN DPKO 2008, 2006). Supporting the provision of humanitarian aid and the protection of civilians became further core aims of peacekeeping. Integrative or multi-dimensional UN peacekeeping operations have even begun to pay some attention to improve governance at the community level.

Researchers developed new typologies of UN missions to account for the variations in the scope and mandates of missions. For example, Ratner (1996) identifies several criteria to distinguish 'new' from 'traditional' peacekeeping. Also Diehl and Balas (2014) suggest classifying UN missions based on core tasks and practices in order to provide a relevant framework to evaluate their success. Scholars have also observed that missions tend to mutate and transform. Often in response to changing ground conditions, the UN regularly expands mission mandates, redefining their goals and modifying their tasks (Bellamy, Williams and Griffin 2010; Talentino 2004). Howard (2008) concludes, however, that the ability of the UN to adapt to changing conditions on the ground and to learn from mistakes is largely limited within missions, while mistakes are repeated across missions. Interestingly, Howard's (2008) study can be regarded as a transition period in research where the focus shifted away from internal UN politics to the experience of UN peacekeeping missions in the field.

\section{Providing Peacekeepers}

The expansion of peacekeeping both in terms of breath and scope has led to new research questions and debates on the nature and aims of such missions. In particular, quantitative comparative research has become increasingly important as a methodological approach but also in terms of theory development. It has been especially successful in challenging common perceptions on where peacekeepers are deployed and whose interests are served.

The common perception in the public but also among policy makers is that peacekeeping missions deploy in the so-called easy cases, while they avoid difficult, controversial conflicts. A similar line of criticism is that UN missions primarily reflect the national interests of the P-5. Both arguments reflect a rather pessimistic view on the role of the UN in managing global peace. Yet empirical research suggests that the UN peacekeeping missions neither focus on easy cases nor merely promote 
neo-liberal interests. In effect, the answer to the question 'whose peace is kept' has become increasingly complex.

Large-n quantitative research suggests that, if anything, UN missions intervene in socalled 'hard' cases (Gilligan and Stedman 2003; Fortna 2004, 2008b; Hultman 2010). Peacekeepers are predominantly deployed to countries with a lack of governance capacity. Here the task for building a stable peace is rendered difficult as democracy and stable institutions are in short supply and the legacy of war includes large number of civilian casualties (Ruggeri, Dorussen, and Gizelis 2016a). Recent evaluations of the effectiveness of peacekeeping recognize that this makes it more challenging for the UN to generate successful outcomes (Beardsley and Schmidt 2012; Gilligan and Sergenti 2008; Hegre, Hultman, and Nygård 2010, Ruggeri, Dorussen, and Gizelis 2016b).

Regarding the specific mandates of missions, research suggests that humanitarian concerns and the severity of conflict often motivate decisions of the Security Council. In one of the first systematic studies of possible bias in UN peacekeeping, Gilligan and Stedman (2003: 38) report conflict severity, measured in terms of causalities, as the key factor for intervention. Humanitarian and security concerns mainly motivate UN operations, but at least in the period directly following the end of the Cold War there may have been a regional bias in favor of Europe and the western hemisphere. Fortna and de Jonge Oudraat similarly argue that the UN tends to intervene in more severe conflicts (Fortna 2004, 2008a, 2008b; de Jonge Oudraat 1996). Beardsley and Schmidt (2012) examine 210 international crises from 1945-2002 and find that although the overlap or conflict of national interests of the five permanent members of the Security Council indeed influences and constraints the ability of the UN to act in international crises, the severity of conflicts remains a more important predictor of UN intervention. Benson and Kathman (2014) offer a similarly nuanced explanation of when the UN deploys peacekeepers in a civil conflict. By looking at the UN Security Council (UNSC) resolutions on African civil wars in the period 1990-2008, they find that the resolutions reflect a bias towards the war outcome; i.e., forces are more likely to be deployed when the side that the UNSC members favor is experiencing heavy losses. At the same time, even recognizing possible bias in where $\mathrm{UN}$ forces are deployed, they also note that the willingness to protect civilians and 
end hostilities is an important element of the calculus to intervene. Allen and Yuen (2014) also link the flexibility of the mandate and operational latitude of a mission to the interests of the P-5 members and their links with war-torn societies.

Of course, even if the UN intervenes in more violent or difficult conflicts, countries that contribute peacekeepers could still be concerned about the welfare of their troops and limit where and how they are deployed. Peacekeepers may end up in relatively safe areas with reliable infrastructure close to their headquarters and major urban areas (Autesserre 2008, 2010). Using disaggregate data, recent research has looked at the factors behind UN deployment at the sub-national level (Costalli 2014; Diehl 2014; Hultman, Kathman, and Shannon 2015; Powers, Reeder, and Townsen 2015; Ruggeri, Dorussen, and Gizelis 2016a). Costalli (2014) studies sub-national variation in the presence of UN peacekeepers in Bosnia and highlights that UN tends to be active where there was high level of violence against civilians. Ruggeri, Dorussen, and Gizelis (2016a), also using data on conflict and peacekeeping deployment at the grid level, find that peacekeepers tend to be deployed in areas of conflict but with a significant lag of roughly two years. Moreover, for large countries like the Democratic Republic of Congo (DRC) accessibility to urban areas influences the pattern of deployment in conflict regions.

Regardless, countries subject to peacekeeping missions overwhelmingly belong to the 'global south' as critical theorists rightly highlight and problematize (Wyeth 2012). Critics of the liberal peace (e.g., Paris 2002) argue that most international organizations internalize the political and economic values of the wealthy liberal democracies while nearly all of the countries hosting peacebuilding missions are poor and politically weak. Peacebuilding becomes a project to bring war-shattered states into line with prevailing international standards that define how states should organize themselves (Chandler 2004; Joshi, Lee, and MacGinty 2014; Paris 2002: 638).

Whereas the wealthy liberal democracies still carry the largest financial burden of peacekeepers (Khanna, Sandler, and Shimizu 1999), they are no longer the main contributors on peacekeeping personnel. Historically, neutral countries like Sweden used to provide the bulk of troops to the small and neutral peacekeeping missions. A much larger group of countries has been needed to meet the growth in demand for 
peacekeepers since the 1990s, and increasingly countries that belong to the 'global south' provide the bulk of peacekeeping personnel (Bove and Elia 2011). As of April 2015 the UN missions include 107565 uniformed personnel -uniformed personnel includes troops, police forces and military observers—from 121 countries. The top 5 contributors are Bangladesh, Pakistan, India, Ethiopia and Rwanda, while China is among the top 10 contributors.

The composition of UN peacekeeping missions has raised questions about the effectiveness of missions (Bove and Ruggeri 2015; Doyle and Sambanis 2006; Hultman, Kathman, and Shannon 2013), the pattern of deployment of UN forces (Fortna 2008a, 2008b), but also the politics of burden sharing (Cunliffe 2013; Gaibulloev, Sandler, and Shimizu 2009; Gaibulloev et al. 2015; Shimizu and Sandler 2002, 2010). Ward and Dorussen (2016) demonstrate countries with similar policy preferences - as demonstrated in their voting behavior in the UN General Assembyare more likely to contribute troops to particular missions. The current model of peacekeepers' provision has however led to debates on the sustainability of missions and on how to provide incentives to participating countries given the exceeding demands for larger missions of more than 12,000 uniformed personnel (Bellamy and Williams 2013; Coleman 2014).

The differences between the countries that finance UN missions and the countries that consistently contribute troops have raised questions about the aims of peacekeeping missions. Cunliffe (2013) argues that, in its current form of financing, cosmopolitan UN peacekeeping represents liberal imperialism. He compares modern peacekeepers to the 'sepoy' forces of the Indian army or the 'askari' of the African colonial armies. The peacekeepers from the 'global south' in effect secure and protect the interests of the powerful Northern countries that dominate the UN Security Council. Whereas Gaibulloev et al. (2015) argue that the remuneration of peacekeeping forces leads to donor-specific benefits for contributing countries, and thus represents a redistribution of resources from developed to developing countries, Cunliffe warns that the specialization of Southern governments in providing peacekeepers undermines their democratic institutions because the military's elevation in such prominent role threatens the democratic polity (Cunliffe 2013: 212). 
Victor's (2010) study on African contributors of troops shows that, at least in the case of regional missions, poorer countries with lower state legitimacy tend to participate more often in regional peacekeeping. Regional peacekeeping, however, also poses an important challenge to critical studies, since in the cases of the Organization of American States (OAS) and the African Union (AU) peacekeeping is not a further example of Northern 'liberal imperialism'. The divergent approaches to peacekeeping between empirical research and critical theory are also pronounced with respect to quality of the peace that peacekeeping missions provide.

\section{The Effectiveness of Peacekeeping}

A number of case studies (e.g., Clarke and Herbst 1997; Durch 1996; Durch et al. 2003; Paris 2004; Weiss 1995) were published in the aftermath of two tragic incidents in the history of peacekeeping: the spectacular failure of the United Nations Assistance Mission for Rwanda to prevent or even minimize the magnitude of the Rwanda genocide and the ineffective missions in Somalia (UNITAF and UNOSOM I and II). Understandably, these studies highlighted the failures of peacekeeping emphasizing how shifting situations on the ground left UN peacekeepers with inappropriate mandates and insufficient capacity to intervene effectively. While emphasis was on the organizational capacity of peacekeeping, there was less understanding of the changing nature of global patterns of conflict and the challenges that the predominance of intrastate conflicts presented for UN peacekeeping and missions. The meaning of peace in the context of intrastate conflicts had fundamentally altered, and so did the expectations of what constitutes an effective peacekeeping mission.

Since 2000s there have been two major changes in the study of peacekeeping. The seminal Doyle and Sambanis study in 2000 introduced the use of quantitative methods in the analysis of peacekeeping. The use of quantitative methods mirrored methodological and epistemological changes in the study of conflict, especially civil and intrastate wars. The proliferation of new datasets such as the Uppsala/PRIO Armed Conflict Dataset (Gleditsch et al. 2002) and most recent development of the Uppsala Conflict Data Program (UCDP) among others allowed researchers to develop more comprehensive theoretical and empirical models of assessing the performance 
of UN missions in containing or ending violent armed conflict. Simultaneously, study of Doyle and Sambanis was indicative of a theoretical shift where the interactions between the UN peacekeepers and the local actors (either the government or populations) were recognized as important in understanding the impact of UN missions on conflict management and resolution. Doyle and Sambanis developed a more comprehensive theoretical model of not just peacekeeping but also peacebuilding, where external actors supplement the local capacity highlighting the role of 'peacekept' in the process (Fortna 2008b; Dorussen 2015).

The findings of initial systematic and quantitative comparative studies showed that UN peacekeeping can be an effective method of conflict management. Quantitative studies almost invariably find that peacekeeping reduces the likelihood of conflict recurrence (Doyle and Sambanis 2000, 2006). Fortna (2003, 2004, 2008a, 2008b); Gilligan and Sergenti (2008); Hegre, Hultman, and Nygård (2011); and Sambanis and Doyle (2007) have shown that the impact of peacekeeping is not simply a matter of selection bias: if anything, the UN selects 'hard' cases - civil conflicts with high casualty levels that have been on-going and incompletely settled - making the record of peacekeeping even more remarkable. Most studies control for possible selection bias via matching methods, however recently, Ijaz (2014) proposes the supply of peacekeepers and Vivalt (2015) the rotation within the UN Security Council as instruments for the non-random assignment of peacekeeping.

The quantitative literature identifies several mechanisms through which peackeeping missions influence the likelihood of peace in a post-conflict country. Doyle and Sambanis (2006) link the impact of peacekeepers to the broader agenda of new peacekeeping. The comparative advantage of UN missions is not the use of force, but rather the ability to mediate and implement comprehensive peace agreements. Fortna (2008b), building on the civil war literature that conceptualizes armed conflict as bargaining failure, argues that peacekeeping can increase the likelihood of peace by reducing uncertainty between the fighting parties. Peacekeeping facilitates the flow of information and increase the credibility of any commitments made by warring parties; for example, by means of dealing with potential spoilers. In one of the few studies that compare UN missions to regional non-UN peacekeeping, Heldt (2004) finds only minor differences between the effectiveness of UN and non-UN peacekeeping. Yet, 
he points out that $\mathrm{UN}$ peacekeeping remains the most comprehensive instrument of the international community for peacebuilding. Recent research explores the complementarities between UN and regional organizations with elements of resource pooling to support complex missions (Brosig 2014).

The findings of quantitative research sharply contrast with the conclusions reached by most qualitative case studies and ethno-graphic research. Radically different conceptualization of peace and effectiveness can to some extent explain the opposing conclusions. Qualitative and ethno-graphic research offers a more pessimistic view on the effectiveness of peacekeeping missions to keep the peace not only because it applies more comprehensive and demanding definition of effectiveness but also because it considers experiences at the local and the micro-level rather than at the level of the country or the mission. Peace becomes a multilevel concept separate from war rather than the mere absence of armed conflict (Olsson 2009; Olsson and Gizelis 2014). The conceptualization of peace as 'positive' raises the questions of who benefits from peace and what does peace mean for different groups within a country, in other words peace for whom? In other cases researchers conceptualize 'peace' as a process leading to questions of who is providing 'peace' (Barnett, Fang, and Zürcher 2014; Paris and Sisk 2009; Pouligny 2006). Thus, the concept of peace is linked to the experiences and perceptions the local populations or 'peacekept' as we examine in the next section.

The broader liberal governance agenda has also become an object of criticism. Critical studies theorize peacekeeping as an instrument of the international community to impose global (i.e., Western) values and norms on 'weak' countries (Barnett 1995; Gibbs 1997; Jakobsen 1996; Joshi, Lee and MacGinty 2014; Ignatieff 2003; Richmond 2014). Weinstein (2005) and Herbst (2003) have questioned whether external intervention can ever succeed at peace- and statebuilding, and instead argue for endogenously supported processes. Roland Paris $(1997,2004)$ discusses the limits of the liberal democratic peace for post-conflict countries with historically weak states. He argues that true legacy of peace-building is often little more than giving quasiauthoritarian leaders an opportunity to hold on to power via quasi-democratic elections. 
When the concept of peace is expanded to include multiple dimensions then peacekeeping operations are often seen as dysfunctional and ineffective (Cambell, Chandler, and Sabratham 2011). There are serious concerns about the quality of peacekeepers provided. The limited willingness of countries that have sent peacekeepers to accept casualties compounds the lack of interest by major powers to sustain peacekeeping missions. Inter-organizational communication is slow and regularly fails to deliver the support needed on the ground. Autesserre's $(2010,2014)$ narratives of the organizational biases within the United Nations Mission in Congo (MONUC) further illustrate the impact that dominant cultures within the organization have on the mission's effectiveness to address local conflicts (also see Moore 2013). Recent methodological developments in the study of civil wars allow researchers to use data that vary across time and space at different levels of analysis. As a result, quantitative researchers have started exploring local variations in order to assess the capacity of peacekeeping missions to contain conflict and save lives. While the definition of 'peace' remains quite minimalist, the high level of granularity of the data allow for studies to answer basic questions on the effectiveness of peacekeeping. The current studies converge on the key findings that UN peacekeeping reduces the duration of conflict in a particular location, contains the space of armed conflict, and protects civilians (Beardsley 2011; Gleditsch and Beardsley 2015; Hultman, Kathman, and Shannon 2013, 2014; Ruggeri, Dorussen, and Gizelis 2016b). Regional (sub-national) variations in local capacities can explain variation in outcomes in the performance of peacekeeping operations and from within country comparisons a nuanced picture emerges of how the local interacts with the global (Gizelis 2011).

\section{What about the 'Peacekept'?}

Whereas traditional peacekeeping represents a top-down approach clearly aimed at encouraging political leaders to honor the terms of peace agreements, comprehensive peacekeeping also encompasses bottom-up approaches and recognizes the valuable contributions to be made locally at the grassroots level. Peacekeepers often have a very limited understanding of local conditions and (unsurprisingly given the need of a small number of peacekeepers to control a large area) limited presence on the ground (Ruggeri, Dorussen, and Gizelis 2016a). A further complaint is the frequent rotation of peacekeepers (Autesserre 2010). Pouligny (2006) highlights the big difference between the official version of peacekeeping and local sentiments. Similarly, 
Dorussen (2015) found in Timor Leste that the official version of peacekeepers building capacity of local policemen to differ markedly from the local version in which peacekeepers are good 'taxi-drivers' with off-roaders that can take you anywhere and good at fixing computers. Furthermore, critical international relations scholars observe that the more recent emphasis on regional peacekeeping runs the risk of a divergence between low (mainly African) and high (Western) quality of peacekeeping (Bellamy, Williams, and Griffin 2010).

The literature on peacekeeping at the micro level has to deal with a number of challenges. Firstly, it needs to be established who are the key actors in keeping peace. Especially in a post-conflict environment, governments tend to be weak with limited control over its population and territory. Rebel groups regularly participate in peace negotiations and sign peace agreements, but little is known about their organizational structures and their potential role in a post-conflict environment. Approaches that focus on the society level emphasize the role of local communities and civil society organizations in interacting with the central government or with external actors and international organizations (Dorussen and Gizelis 2013; Gizelis 2009, 2011; Ruggeri, Dorussen, and Gizelis 2013). Expanding the set of relevant actors also broadens the definition of peace, since different actors will have different expectations about what peace is for them. Research on peacekeeping at the micro-level has to consider what, if any, the implications are for how to conceptualize and measure peace. Importantly, different definitions of peace may imply different expectations on how local actors respond to peacekeeping missions (da Costa and Karlsrud 2014).

The diverse conceptualization of peace is a key dividing line between empirical quantitative research and critical studies, as well as qualitative single cases. In quantitative research 'peace' does not have a specific content, but rather it signifies the absence of violent conflict. In this research tradition, the longevity of peace is of interest and the key milestone to evaluate the performance and effectiveness of a mission (Olsson and Gizelis 2014). The content or the quality of peace, however, brings forward questions about institutional formation, governance, and ultimately the nature of societies and states that emerge through interaction with external actors (Bieber 2005; Barnett, Fang, and Zürcher 2014). In a similar line of research, feminist theorists have highlighted the importance of the quality of peace for women in 
particular. Olsson (2009) outlined the different implications of peacekeeping and post-conflict reconstruction for the security and political participation of men and women. While feminist theorists have historically dominated research on gender and peacekeeping, more recent empirical research has attempted to further integrate gender into mainstream research on peacekeeping (Gizelis and Olsson 2015; Olsson and Gizelis 2014; Olsson and Tryggestad 2001). Gendering peacekeeping becomes particularly salient for security sector reform and political participation signifying new areas of theoretical development to improve our understanding of peacekeeping effectiveness (Gizelis and Olsson 2015; Karim and Beardsley 2013).

Bottom-up approaches not only emphasize the importance of local non-governmental and grassroots organizations in reconstruction (Lederach 2008), but also their role in sustaining (and undermining) peace processes. Peacebuilding policies emphasize the importance of local dialogue and capacity-building, and appeal to local actors; yet they do so through an international template that is overly technical, depoliticizing, and often exclusionary (Paris 2002). Influential reports, such as Annan's (2005) Larger Freedom: Towards Development, Security and Human Rights for All, promote the idea that the UN system dealing with a very different international system requires a new governance-based approach promoting partnerships and local ownership. This approach to peacebuilding seeks to strengthen individual, local and national capacities, building institutions, instigating good governance and enhancing economic opportunities. International organizations, governments, and INGOs have adopted a discourse of capacity building that places more emphasis on local institutions and civil society. Significantly, this highlights the need for good governance to address failures in reconstruction and development as the result of poor institutions and weak capacity. The governance dimension is essential to let people use their power and resources to maximum effect.

In contrast, top-down peacebuilding approaches tend to focus on elites and establishing functioning institutions in a country after violent conflict (Donais 2012; Paris 1997). Local civil societies and grassroots organizations are generally seen as fragmented, weak, and lacking capacity to fully participate and engage with the peacekeeping and, ultimately, peacebuilding process (Lefranc 2013; Pouligny 2006). At the same time, the literature on peacebuilding commonly attributes failures in post- 
conflict reconstruction to the top-down imposition of policies and values on local populations (Autesserre 2014; Paris and Sisk 2009).

While initially only qualitative empirical researchers focused on grassroots organizations, increasingly quantitative studies move beyond the central government and the rebels as key actors and explore non-state actors and their role in peacekeeping (Dorussen and Gizelis 2013). The findings are often mixed. Autesserre (2008, 2010), Pouligny (2006) and others such as Richmond (2014) and Basini (2013) are highly critical of the failures of peacekeeping missions to integrate local actors in the peacebuilding processes. Peacekeepers often have a very limited understanding of local conditions and often only limited presence on the ground. This is attributed to the structures of the missions, the rotation of peacekeepers and organizational employees, organizational failures, and finally ideological perspectives that limit the ability of understanding local conditions (Autesserre 2010; Diehl and Druckman 2010) Limited experimental evidence and semi-structured interviews, however, offer an interesting nuance on how different populations among locals perceive the UN missions suggesting that among local populations, women and vulnerable groups tend to be more positive towards UN peacekeeping missions rather than men or local elites (Dorussen 2015; Olsson and Gizelis 2014).

Critical and qualitative researchers who examine the synergies between local actors both elites, but also at the grassroots level, have highlighted the emergence of 'hybrid peace governance' in post conflict countries that experience peacebuilding missions (Belloni 2012; Bjorkdahl and Hoglund 2013; MacGinty 2008, 2010; Millar, van der Lijn and Verkoren 2013; Richmond and Mitchell 2013). The authors on 'hybrid peace' are primarily concerned with the characteristics of 'peace' that emerges in the wake of peacekeeping operations.

\section{Conclusions}

UN peacekeeping missions have evolved from the small missions of barely 300 personnel in the wake of WWII to the large comprehensive missions with more than 15,000 military personnel and complex mandates. In practice, peacekeepers are now deployed into more challenging situations that involve complex protracted conflicts. They are also given broader and more challenging mandates to complete a wide range 
of tasks involving local actors both at the elite and the grassroots levels. Given the complexity of contemporary missions, we may have expected peacekeeping to fail more often. And yet, existing research suggests that despite limitations and challenges, UN missions often are successful in saving lives.

Research has mirrored the transformation of the UN missions and established new and higher standards to measure the effectiveness and success of peacekeeping. Effective missions should not only provide negative peace by stopping conflict and sustain the post-agreement duration of peace, but also positive peace. The concept of positive peace expands to include the protection of civilians and vulnerable groups of people from residual violence, security sector reform, building state capacity and even support democratization and economic development. Adding to the increasing long list of expectations of building societies, UN missions are often expected to monitor borders, improve stability in conflict 'hot spots' and deter 'spoilers' from challenging the national peace agreements.

In light of the increased expectations of what constitutes a successful UN peacekeeping mission, any positive findings from both quantitative and qualitative research are actually quite remarkable (Goldstein 2011). The conventional wisdom is that UN peacekeeping is ineffective, yet the review of the existing literature suggests that we not only demand more and more from the blue helmets, but that peacekeepers actually often deliver beyond expectations. Future research needs to highlight the baseline against which UN peacekeeping missions can be benchmarked for a more realistic perspective on peacekeeping to emerge among academics, policy makers, and the public opinion. 


\section{Bibliography}

Allen, S. H. \& Yuen, A. T. (2014). The Politics of Peacekeeping: UN Security

Council Oversight Across Peacekeeping Missions. International Studies Quarterly, 58(3), 621-632.

Annan, K. (2005) In Larger Freedom: Towards Development, Security and Human

Rights for All. Report of the Secretary General. UN document A/59/2005.

Autesserre, S. (2008). The Trouble with Congo: How Local Disputes Fuel Regional Conflict. Foreign Affairs, 87(3), 94-110.

------- (2010). The Trouble with the Congo: Local Violence and the Failure of International Peacebuilding. Cambridge: Cambridge University Press.

------ (2014). Going Micro: Emerging and Future Peacekeeping Research.

International Peacekeeping, 21(4), 492-500.

Barash, D. P. \& Webel, C. (2002). Peace and Conflict Studies. Thousand Oaks: Sage Publications.

Barnett, M. (1995). The New United Nations Politics of Peace: From Juridical Sovereignty to Empirical Sovereignty. Global Governance, 1(1), 79-97.

---- (2002). Eyewitness to a Genocide: The United Nations and Rwanda. Ithaca, NY: Cornell University Press.

Barnett, M., Fang, S. \& Zürcher, C. (2014). Compromised Peacebuilding. International Studies Quarterly, 58(3), 608-620.

Basini, H. S. A. (2013). Gender Mainstreaming Unraveled: The Case of DDRR in Liberia. International Interactions, 39(4), 535-557. 
Beardsley, K. (2011). Peacekeeping and the Contagion of Armed Conflict. Journal of Politics, 73(4), 2011, 1051-6.

Beardsley, K. \& Schmidt, H. (2012). Following the Flag or Following the Charter? Examining the Determinants of UN Involvement in International Crises, 1945-2002. International Studies Quarterly, 56(1), 33-49.

Bellamy, A. \& Williams, P. (2013). (eds.) Providing Peacekeepers: The Politics, Challenges, and Future of United Nations Peacekeeping Contributions. Oxford: Oxford University Press.

Bellamy, A. J., Williams, P. \& Griffin, S. (2010). Understanding Peacekeeping. Cambridge, UK: Polity.

Belloni, R. (2012). Hybrid Peace Governance: Its Emergence and Significance. Global Governance, 18(1), 21-38.

Benson, M. \& Kathman, J. D. (2014). United Nations Bias and Force Commitments in Civil Conflicts. The Journal of Politics, 76(2), 350-363.

Bieber, F. (2005). Local Institutional Engineering: A Tale of Two Cities, Mostar and Brc`ko. International Peacekeeping, 12(3), 420-33.

Birger, H. (2004). UN-led or Non-UN-led Peacekeeping Operations?. Journal of International Politics, 9(2), 113-139.

Bjorkdahl, A. \& Hoglund, K. (2013). Precarious Peacebuilding: Friction in GlobalLocal Encounters. Peacebuilding, 1(3), 289-99.

Boutros-Ghali, B. (1992). An Agenda for Peace. Preventive Diplomacy, Peacemaking, and Peace-keeping. Report of the Secretary-Gerneral. Doc a/47/277S/2411. New York, NY: United Nations. 
Bove, V. \& Elia, L. (2011). Supplying Peace: Participation in and Troop Contribution to Peacekeeping Missions. Journal of Peace Research, 48(6), 699-714.

Bove, V. \& Ruggeri, A. (2015). Kinds of Blue. Diversity in U.N. Peacekeeping Missions and Civilian Protection. British Journal of Political Science. Forthcoming.

Brosig, M. (2014). EU Peacekeeping in Africa: From Functional Niches to Interlocking Security. International Peacekeeping, 21(1), 74-90.

Call, C. T. \& Cousens, E. M. (2008). Ending Wars and Building Peace: International Responses to War-Torn Societies. International Studies Perspectives, 9, 1-21.

Campbell, S., Chandler, D. \& Sabaratnam, M. (2011). (eds.) A Liberal Peace? The Problems and Practices of Peacebuilding. London: Zed Books.

Chandler, D. (2004). The Responsibility to Protect? Imposing the "Liberal Peace". International Peacekeeping, 11(1), 59-81.

Chesterman, S. (2005). You, The People: The United Nations, Transitional Administration, and State-Building. Oxford: Oxford University Press.

Clarke, W. \& Herbst, J. (1997). (eds.) Learning from Somalia: The Lessons of Armed Humanitarian Intervention. Boulder, CO: Westview.

Coleman, K. P. (2014). The Political Economy of UN Peacekeeping: Incentivizing Effective Participation. New York: International Peace Institute.

Costalli, S. (2014). Does Peacekeeping Work? A Disaggregated Analysis of Deployment and Violence Reduction in the Bosnian War. British Journal of Political Science, 44(2), 357-380.

Cunliffe, P. (2013). Legions of Peace: UN Peacekeepers from the Global South. London: Hurst. 
da Costa, D. F. \& Karlsrud, J. (2012). Contextualising Liberal Peacebuilding for Local Circumstances: UNMISS and Local Peacebuilding in South Sudan. Journal of Peacebuilding \& Development, 7(2), 53-66.

de Jonge Oudraat, C. (1996). The United Nations and Internal Conflict. In Brown, M.E. (ed.) The International Dimensions of Internal Conflict. Cambridge, MA: MIT Press.

Diehl, P. F. (2014). Behavioural Studies of Peacekeeping Outcomes. International Peacekeeping, 21(4), 484-491.

Diehl, P. F. \& Balas, A. (2014). Peace Operations (2nd ed.). Cambridge: Polity Press.

Diehl, P. F. \& Druckman, D. (2010). Evaluating Peace Operations. Boulder, Colo.: Lynne Rienner Publishers.

Diehl, P. F., Reifschneider, J. \& Hensel, P. R. (1996). United Nations Intervention and Recurring Conflict (Research note). International Organization, 50(4), 683-700.

Donais, T. (2012). Peacebuilding and Local Ownership: Post-Conflict ConsensusBuilding. New York: Routledge.

Dorussen, H (2015). Security Perception after the Completion of UN Peacekeeping in Timor-Leste. Peace Economics, Peace Science and Public Policy. Forthcoming.

Dorussen, H. \& Gizelis, T.-I. (2013). Into the Lion's Den: Local Responses to UN Peacekeeping. Journal of Peace Research, 50(6), 693 - 708.

Doyle, M. W. \& Sambanis, N. (2000). International Peacebuilding: A Theoretical and Quantitative Analysis. American Political Science Review, 94, 779-802.

---- (2006). Making War and Building Peace: United Nations Peace Operations. Princeton, N.J: Princeton University Press. 
Duffield, M. (2014). Global Governance and the New Wars: The Merging of Development and Security. London: Zed Books.

Durch, W. J. (1996). UN Peacekeeping, American Policy and the Uncivil Wars of the 1990s. New York: St. Martin's.

Durch, W., Holt, V.K., Earle, C.R. \& Shanahan, M.K. (2003) (eds.) The Brahimi Report and the Future of UN Peace Operations. Washington, D.C.: The Henry J. Stimson Center.

Fortna, V. P. (2003). Scraps of Paper?: Agreements and the Durability of Peace. International Organization, 572, 337-372.

----- (2004). Interstate Peacekeeping: Causal Mechanisms and Empirical Effects. World Politics, 564, 481-519.

---- (2008a). Does Peacekeeping Keep Peace?: International Intervention and the Duration of Peace after Civil War. International Security and Conflict, 557-580.

---- (2008b). Does Peacekeeping Work?: Shaping Belligerents' Choices after Civil War. Princeton: Princeton University Press.

Gaibulloev, K., Sandler, T., \& Shimizu, H. (2009). Demands for UN and non-UN peacekeeping: Nonvoluntary versus voluntary contributions to a public good. Journal of Conflict Resolution, 53(6), 827-852.

Gaibulloev, K., George, J., Sandler, T. \& Shimizu, H. (2015). Personnel Contributions to UN and Non-UN Peacekeeping Missions: A Public Goods Approach. Journal of Peace Research.

Galtung, J. (1964). An Editorial. Journal of Peace Research, 1(1), 1-4.

Gibbs, D. N. (1997). Is Peacekeeping a New Form of Imperialism? International Peacekeeping, 4(1), 122-28. 
Gilligan, M. J., Beber, B., Guardado, J. \& Karim, S. (2012). UN Peacekeeping and Transactional Sex in Monrovia, Liberia. Paper presented at the Folke Bernadotte Working Group on Peacekeeping, New York.

Gilligan, M. J., Pasquale, B. \& Samii, C. (2014). Civil War and Social Cohesion: Labin-the-Field Evidence from Nepal. American Journal of Political Science, 58(3), $604-619$.

Gilligan, M. J. \& Sergenti E. J. (2008). Do UN Interventions Cause Peace? Using Matching to Improve Causal Inference. Quarterly Journal of Political Science, 3, 89122.

Gilligan, M. \& Stedman, S. J. (2003). Where Do the Peacekeepers Go?. International Studies Review, 5(4), 37-54.

Gizelis, T.- I. (2009). Gender Empowerment and United Nations Peacebuilduing. Journal of Peace Research, 46(4), 505-23.

----- (2011). A Country of Their Own: Women and Peacebuilding. Conflict Management and Peace Science, 28(5), 522-42.

Gizelis, T-I. \& Olsson, L. (2015) (eds.) A Systemic Understanding of Gender, Peace and Security: Implementing UNSCR 1325. Routledge. Forthcoming.

Gleditsch, K. \& Beardsley, K. (2015). Peacekeeping as Conflict Containment. International Studies Review, 17(1), 67-89.

Gleditsch, N. P., Nordkvelle, J. \& Strand, H. (2014). Peace Research - Just the Study of War?. Journal of Peace Research, 51(2), 145-158.

Gleditsch, N. P., Wallensteen, P., Eriksson, M., Sollenberg, M. \& Strand, H. (2002). Armed Conflict 1946-2001: A New Dataset. Journal of Peace Research, 39(5), 615637. 
Goldstein, J. S. (2011). Winning the War on War: The Decline of Armed Conflict Worldwide. New York, NY: Dutton.

Goulding, M. (1993). The Evolution of United Nations Peacekeeping. International Affairs, 69(3), 451-64.

Hegre, H., Hultman, L. \& Nygård, H. M. (2010). Evaluating the Conflict Reducing Effects of UN Peace-Keeping Operations. Paper presented at American Political Science Association Annual Meeting, 1-5 September.

Heldt, B. (2004). UN-led or Non-UN-led Peacekeeping Operations?. IRI Review, 9, $113-138$

Herbst, J. (2003). Let Them Fail: State Failure in Theory and Practice: Implications for Policy. In Rotberg, R. I. (ed.) When States Fail: Causes and Consequences. Princeton University Press, Princeton, NJ.

Howard, L. M. (2008). UN Peacekeeping in Civil Wars. Cambridge, UK: Cambridge University Press.

Hultman, L. (2010). Keeping Peace or Spurring Violence? Unintended Effects of Peace Operations on Violence against Civilians. Civil Wars, 12, 29-46.

Hultman, L., Kathman, J. \& Shannon, M. (2013). United Nations Peacekeeping and Civilian Protection in Civil War. American Journal of Political Science, 57(4), 875 891.

----- (2014). Beyond Keeping Peace: United Nations Effectiveness in the Midst of Fighting. American Political Science Review, 108(4), 737-753.

----- (2015). United Nations Peacekeeping Dynamics and the Duration of Post-civil Conflict Peace. Conflict Management and Peace Science. Forthcoming. 
Ignatieff, M. (2003). Empire Lite: Nation-Building in Bosnia, Kosovo, and Afghanistan. London: Vintage.

Ijaz, S. S. (2014). The Selection Problem in Peacekeeping Missions: Developing an Instrumental Variable. Working Paper NYU New York.

Jakobsen, P. V. (1996). National Interest, Humanitarianism or CNN: What Triggers UN Peace Enforcement after the Cold War?. Journal of Peace Research, 33(2), 20515.

Joshi, M., Lee, S. Y. \& MacGinty. R. (2014). Just How Liberal Is the Liberal Peace?. International Peacekeeping, 21(3), 364-389.

Karim, S. \& Beardsley, K. (2013). Female Peacekeepers and Gender Balancing: Token Gestures or Informed Policymaking?. International Interactions, 39(4), 461488.

Khanna, J., Sandler, T. \& Shimizu, H. (1999). The demand for UN peacekeeping: 1975-1996. Kyklos, 52(3), 345-368.

Lederach, J. P. (2008). Building Peace: Sustainable Reconciliation in Divided Societies. Washington, D.C.: United States Institute of Peace Press.

Lefranc, S. (2013). A Critique of "Bottom-Up" Peacebuilding: Do Peaceful Individuals Make Peaceful Societies?. In Charbonneau, B. \& Parent, G. (eds.) Peacebuilding, Memory and Reconciliation: Bridging Top-Down and Bottom-Up Approaches. New York: Routledge.

MacGinty, G. R. (2008). Indigenous Peace-Making versus the Liberal Peace. Cooperation and Conflict, 43(2), 139-63.

----- (2010). Hybrid Peace: The Interaction Between Top-Down and Bottom-Up Peace. Security Dialogue, 41(4), 391-412. 
Migdal, J.S. (1988). Strong Societies and Weak States: State-Society Relations and State Capabilities in the Third World. Princeton: Princeton University Press.

Millar, G., van der Lijn, J. \& Verkoren, W (2013). Peacebuilding Plans and Local Reconfigurations: Frictions between Imported Processes and Indigenous Practices. International Peacekeeping, 20(2), 137-43.

Moore, A. (2013). Peacebuilding in Practice: Local Experience in Two Bosnian Towns. Ithaca, NY: Cornell University Press.

Mvukiyehe, E. \& Samii, C. (2012), Does Peacekeeping Work from the Bottom Up? Negative Evidence from Liberia, New York University, Working Paper.

Nixon, R. (2006). The Crisis of Governance in New Subsistence States. Journal of Contemporary Asia, 36 (1), 75-101.

Olsson, L. (2009). Gender Equality and United Nations Peace Operations in Timor Leste. Leiden: Martinus Nijhoff Publishers.

Olsson, L. \& Gizelis, T.-I. (2014). Advancing Gender and Peacekeeping Research. International Peacekeeping, 21(4), 520-528.

Olsson, L. \& Tryggestad, T. L. (2001). Women and International Peacekeeping. London: F. Cass.

Paris, R. (1997). Peacebuilding and the Limits of Liberal Internationalism. International Security, 22(2), 54-89.

---- (2002). International Peacebuilding and the 'Mission Civilisatrice'. Review of International Studies, 28(4), 637-656.

---- (2004). At War's End: Building Peace after Civil Conflict. Cambridge, U.K: Cambridge University Press. 
Paris, R. \& Sisk, T. D. (2009). The Dilemmas of Statebuilding: Confronting the Contradictions of Postwar Peace Operations. London: Routledge.

Pouligny, B. (2006). Peace Operations Seen from Below: UN Missions and Local People. London: C. Hurst \& Co.

Powers, M., Reeder, B. W. \& Townsen, A. A. (2015). Hot Spot Peacekeeping. International Studies Review, 17(1), 46-66.

Ratner, S. R. (1996). The New UN Peacekeeping. Building Peace in Lands of Conflict after the Cold War. New York: St Martin's.

Report of the Panel on United Nations Peace Operations (Brahimi Report). (2000). A/55/305 - S/2000/809. United Nations.

Richmond, O. P. (2014). Peace During and After the Age of Intervention. International Peacekeeping, 21(4), 509-519.

Richmond, O. P. \& Mitchell, A. (2011). Hybrid Forms of Peace: From Everyday Agency to Post-Liberalism. New York: Palgrave.

Rotberg, R. I. (2002). (ed.) When States Fail: Causes and Consequences. Princeton, NJ: Princeton University Press.

Ruggeri, A., Dorussen, H. \& Gizelis, T.-I. (2013). Managing Mistrust: an Analysis of Cooperation with UN Peacekeeping in Africa. Journal of Conflict Resolution, 57(3), $387-409$.

----- (2016a). On the Frontline Every Day? Subnational Deployment of United Nations Peacekeepers. British Journal of Political Science, forthcoming.

----- (2016b), Winning the Peace Locally: UN Peacekeeping and Local Conflict. International Organization, forthcoming.

Shimizu, H \& Sandler, T. (2002). Peacekeeping and Burden Sharing, 1994- 
2000. Journal of Peace Research, 39(6), 651-68.

---- (2010). Recent Peacekeeping Burden Sharing. Applied Economics Letters, 17(15), 1479-1484.

Talentino, A. K. (2004). US Intervention in Iraq and the Future of the Normative Order. Contemporary Security Policy, 25(2), 312-338.

Tiernay, M. (2015). Which Comes First? Unpacking the Relationship between Peace Agreements and Peacekeeping Missions. Conflict Management and Peace Science, 32(2), 135-152.

Vivalt, Eva. 2015. Peacekeepers Help, Governments Hinder”. Working Paper NYU New York.

UN DPKO (2006). Gender Equality in UN Peacekeeping Operations. United Nations.

----- (2008). Capstone Doctrine: United Nations Peacekeeping Operations: Principles and Guidelines. United Nations.

Victor, J. (2010). African Peacekeeping in Africa: Warlord Politics, Defense Economics, and State Legitimacy. Journal of Peace Research, 472, 217-229.

Ward, H. \& Dorussen, H. (2016). Standing alongside your friends: Network centrality and providing troops to UN peacekeeping operations, Journal of Peace Research 53(3), 392-408

Weinstein, J. M. (2005). Resources and the Information Problem in Rebel Recruitment. The Journal of Conflict Resolution, 49(4), 598-624.

Weiss, T. G. (1995). The United Nations and Civil Wars. Boulder, CO: Lynne Rienner.

Wyeth, V. (2012). Knights in Fragile Armor: The Rise of the "G7+"'. Global Governance, 18(1), 7-12. 
